WSRC-TR-96-0016

\title{
EVALUATION OF ELEVATED STRONTIUM 89/90 ANALYTICAL RESPONSES - AN INVESTIGATIVE STUDY (U)
}

S. R. Johnson

Westinghouse Savannah River Company

Savannah River Site

Aiken, SC 29808

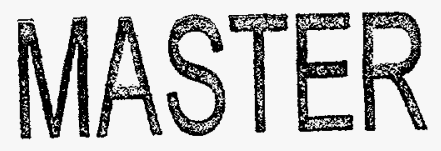

The information contained in this article was developed during the course of work under Contract No. DE-AC09-89SR18035 with the U. S. Department of Energy. By acceptance of this paper, the publisher and/or recipient acknowledges the U.S. Government's right to retain a nonexclusive, royalty-free license in and to any copyright covering this paper along with the right to reproduce, and to authorize others to reproduce all or part of the copyrighted paper. 


\section{DISCLAIMER}

Portions of this document may be illegible in electronic image products. Images are produced from the best available original document. 


\section{DISCLAIMER}

This report was prepared as an account of work sponsored by an agency of the United States Government. Neither the United States Government nor any agency thereof, nor any of their employees, makes any warranty, express or implied, or assumes any legal liability or responsibility for the accuracy. completeness, or usefulness of any information. apparatus, product, or process disclosed. or represents that its use would not infringe privately owned rights. Reference herein to any specific commercial product, process, or service by trade name, irademark, manufacturer, or otherwise does not necessarily constitute or imply its endorsement, recommendation, or fayoring by the United States Government or any agency thereof. The views and opinions of authors expressed herein do not necessarily state or reflect those of the United States -Government or any agency thereof.

This report has been reproduced directly from the best available copy.

Available to DOE and DOE contractors from the Office of Scientific and Technical Information, P. O. Box 62, Oak Ridge. TN 37831: prices available from (615) $576-8401$.

Available to the public from the National Technical Information Service, U. S. Department of Commerce. 5285 Port Royal Rd., Springficld, VA 22161 


\title{
EVALUATION OF ELEVATED STRONTIUM 89/90 ANALYTICAL RESPONSES - AN INVESTIGATIVE STUDY (U)
}

\author{
By S. R. Johnson \\ Westinghouse Savannah River Company \\ Savannah River Site \\ Aiken, SC 29808
}

\section{INTRODUCTION}

For a one week period, erroneously elevated strontium $89 / 90$ readouts, up to 1000 fold, were received from extracted process material analyzed using Liquid Scintillation Counting. While laboratory personnel realized that the responses were higher than historically observed, measurement control indicators were within control limits. An effort was launched to determine probable causes. This paper summarizes those efforts taken to answer:

1) Why did the standard fail to signal an out-of-control method?

2) What were the factors that contributed to the elevated readouts?

Additionally, the corrective actions implemented to preclude other occurrences are discussed.

\section{BACKGROUND}

The methodology for measuring strontium $89 / 90$ involves:

- use of a strontium specific resin (20-50 $\mu$ ) in the extraction columns,

- $\quad$ acidic nitrate $(3 \mathrm{~N})$ column conditioning,

- sample acidification ( $11 \mathrm{~N}$ nitrate), then passage through the column,

- $\quad$ selective resin absorption of strontium, allowing other components to pass through the column,

- additional acidic nitrate wash $(8 \mathrm{~N})$ to elute undesired matrix components that may be remaining on the column,

- water wash to remove strontium from the column cocktail,

- measurement of strontium activity by scintillation counting. 
Radionuclide

Sr-89

Sr-90
Half-Life

52 days

28 years
Beta Emission Region

(avg.)

$583 \mathrm{keV}$

$200 \mathrm{keV}$ (max.)

$1470 \mathrm{keV}$

$544 \mathrm{keV}$

The method was originally developed for the analysis of Reactor Basin samples with tritium activity levels $\leq 0.5 \mu \mathrm{Ci} / \mathrm{mL}$. As the need for the method increased, new and different samples were analyzed with increasing tritium activity and complexity of matrices.

\section{DISCUSSION}

\section{Pertinent Facts}

- The laboratory had been operating without air conditioning for over a month. Temperatures reached near $100^{\circ} \mathrm{F}$, with high humidity.

- Some laboratory electronic equipment had experienced damage, rendering them inoperable, due to humidity conditions.

- The beta emission from tritium is observed at $18 \mathrm{keV}$ energy.

- $\quad$ Nitric acid can generally withstand elevated temperatures.

- The nitric acid extraction reagents were two months old and had traditionally been volumetrically prepared.

- Since the method implementation in 1993, water blank readings had been obtained without the benefit of the extraction technique.

- The strontium standard used was traceable to the National Institute of Standards and Technology (NIST), with a reference date of February, 1994. The standard was composed only of Strontium-90. No constituents had been added to simulate the matrix of process samples.

- Scintillation counter measurements of extracted strontium standards consistently yielded acceptable efficiency statistics, within $85-115 \%$.

- Because effective tritium removal had been achieved historically with low tritiated $(\leq 0.5 \mu \mathrm{Ci} / \mathrm{mL}$ tritium) Reactor Basin samples, the $0-1000$ channel setting had been used for the scintillation counter region of observance.

- Reactor basin samples with $\leq 0.5 \mu \mathrm{Ci} / \mathrm{mL}$ tritium activity have historically observed strontium activity $\leq 1.5 \mathrm{E} 2 \mathrm{~d} / \mathrm{m} / \mathrm{mL}$. 
- Heavy Water waste tank samples, with tritium activity $1-5 \mu \mathrm{Ci} / \mathrm{mL}$ were being analyzed. These samples had previously observed strontium activity that was less than detectable.

\section{Investigation}

Reagents

- There was some concern as to the reagent integrity, with regards to concentration, at the appearance of the erratic results. In the primary stages of the investigation, reagents were changed out to locate the problem. As a result, strontium responses decreased. Hence, the apparent reagent concentration deviation hindered the effectiveness of the extraction.

- Tritium contamination was initially suspected of extraction reagents. While the reagents were discarded before organized investigative efforts proceeded, analysis for tritium was performed prior to the discard.

$$
\begin{array}{cccc}
\text { water } & 114 \mathrm{c} / \mathrm{m} & 8 \mathrm{~N} \mathrm{HNO}_{3} & 78 \mathrm{c} / \mathrm{m} \\
3 \mathrm{~N} \mathrm{HNO}_{3} & 53 \mathrm{~cm} & 11 \mathrm{~N} \mathrm{HNO}_{3} & 259 \mathrm{c} / \mathrm{m}
\end{array}
$$

- Elevated extracted water blank responses (upward to $3 E 2 \mathrm{~d} / \mathrm{m} / \mathrm{ml}$ ) were also experienced during the period of erratic results. The tritium contamination in the water used $(114 \mathrm{c} / \mathrm{m})$ would account for this occurrence.

Resin / Energy Observance Region

- The strontium specific resin exposed to the high temperature and humidity conditions, showed no discoloration or caking.

- A comparative study was conducted with the resin exposed to the abnormal environmental conditions and resin that was not. Newly prepared extraction reagents were used. The scintillation counter energy observation region was adjusted during the study, to observe the response with and without the lower energy region.

\section{Observance Region $0-1000$}

Extracted Process Sample Heat Exposed Resin Unexposed Resin

Reactor Basin

$1 E 2 \mathrm{~d} / \mathrm{m} / \mathrm{mL}$

$2 \mathrm{E} 2 \mathrm{~d} / \mathrm{m} / \mathrm{mL}$

Heavy Water Waste Tank

$6 \mathrm{E} 2 \mathrm{~d} / \mathrm{m} / \mathrm{mL}$

$1 E 3 \mathrm{~d} / \mathrm{m} / \mathrm{mL}$

Reactor Basin, unextracted

$1 E 5 \mathrm{~d} / \mathrm{m} / \mathrm{mL}$ 
WSRC-TR-96-0016

Observance Region $400-1000$

Extracted Process Sample

Reactor Basin

Unexposed Resin

Heavy Water Waste Tank

$<50 \mathrm{~d} / \mathrm{m} / \mathrm{mL}$

Reactor Basin, unextracted

$<50 \mathrm{~d} / \mathrm{m} / \mathrm{mL}$

Less than detectable

Heat Exposed Resin

-.-.-.-
Less than detectable

$3 E 2 \mathrm{~d} / \mathrm{m} / \mathrm{mL}$

A closer probe was conducted into the matter of the energy observance region. This was needed because some strontium-90 would potentially be shielded out and forced low by arbitrary application of the $0-400$ energy observance region. Additionally, this action would verify the broadness of tritium overflow effects. Adverse effects, erratic and elevated readings, were evident in responses through channel 300 .

- An independent laboratory facility analyzed the high tritiated process sample. The results supported those from the investigation.

Extracted Process Sample $0-400 \mathrm{KeV} \quad 400-1000 \mathrm{KeV}$

Heavy Water Waste Tank $>3 \mathrm{E} 2 \mathrm{~d} / \mathrm{m} / \mathrm{mL}$ less than detectable

\section{Conclusions}

- The use of heat exposed strontium specific resin and nitric acid solutions, as related to the elevated scintillation response, are indeterminate.

- Water blanks should be treated the same as samples and standards. Extraction of the water blank assist in the measurement control process of detecting contamination in extraction reagents.

- Extraction removal of tritium from Reactor Basin samples proved effective, as demonstrated by normal responses in the $0-1000$ energy observance region.

- The extraction removal of tritium in Heavy Water Waste Tank samples is incomplete. This observation is independent of the resin and extraction reagents.

- While extraction reagents were discarded before organized investigative efforts, the elevated responses were indicative of tritium bleed-through. However, since successful removal of tritium from Reactor Basin material had been performed in the past without bleed-through, the target reagent concentration is questionable. 
- The strontium standard was incapable of signaling an out-of-control condition in this case because the matrix did not represent that of the samples. A modification of the measurement control system is necessary. Either prepare the standard in a simulated matrix or include in the measurement control system the analysis of a characterized quantity of process material.

- Tritium extraction bleed-through was observed through channel 300 . The scintillation counter must be set to observe channels $400-1000$ only.

- Samples with $>0.5 \mu \mathrm{Ci} / \mathrm{mL}$ tritium activity may experience extraction bleedthrough under normal circumstances. Improvements in the measurement control system, as well as appropriate window settings will preclude the observance of false positive responses.

\section{Corrective Actions}

Methodology

- Scintillation counter energy observance region should be set at $400-1000$.

- Extract the water blank for consistent treatment as other materials.

\section{Measurement Control}

- Maintain a characterized volume of the process material to analyze in addition to the strontium standard. This measurement control system would indicate strontium extraction efficiency and the extraction effectiveness at removing matrix components.

\section{Care of Reagents}

- Incorporate a mechanism for periodic integrity review of extraction reagents. Standardized nitric acids should be utilized for assurance of initial concentration, with periodic integrity checks on that pre-established concentration.

- Extraction reagents should not be stored within the radioactive containment unit. This action would eliminate the question of reagent contamination. 


\section{SUMMARY}

Erroneously elevated strontium responses were observed due to an accumulation of circumstances. Primarily, the incident was caused by failure to revisit the methodology as samples matrices, other than those used to establish the method, were analyzed. As a result, the scintillation counter energy observance window was inappropriately set for sample matrices other than Reactor Basins. Additionally, secondary contributing factors that hindered recognition of the problem included the use of a measurement control system that did not account for matrix effects and uncertainty in the target concentration of extraction reagents. The incorporation of protocol modifications, such as the inclusion of a matrix matched material in the measurement control system, reagent standardization and a heightened awareness of reagent care, should preclude future occurrences. 